\title{
Tkachuk Serhii,
}

Postgraduate, Khmelnytsky University

of Management and Law,

Khmelnytsky, Ukraine

ORCID ID 0000-0002-5102-4446

\section{REGULATORY SUPPORT OF PUBLIC PROCUREMENTS IN UKRAINE}

The article deals with the issues of regulatory and legal support of public procurement in Ukraine. The analysis of the prerequisites for the development of legislation regulating this sphere is carried out. It is noted that the development of the rule of law in Ukraine provides for the creation of an effective mechanism of organizational and legal impact on the participants of public relations, a developed and perfect system of comprehensive regulation of the most important areas of public life in the country. Modern public procurement is no exception, and on the one hand it covers the entire sector of the national economy, but on the other hand it remains one of the most criminalized areas of corruption risks.

It has been noted that the annual reports of the controlling and law enforcement bodies testify to numerous systemic violations committed in this area by the managers of public finances. Inefficient and irrational usage of these resources leads to losses of the country, the size of which is close to the deficit of the state budget

It was indicated that since the legal relations arising in the field of public procurement are directly related to the implementation of the public interest and regulated by the movement of public funds, the main role in this area is played by public-private legal relations, and they are the subject of administrative and legal regulation and support.

In this context, it was also pointed out that the public procurement system remains ineffective, which in turn necessitates further improvement. Reforming of public procurement continued even after the adoption of the Law of Ukraine "On Public Procurement". The legal framework for public procurement in Ukraine is 
generally in line with European Community law, but at the same time is not sufficiently harmonized internally and in some provisions is contrary to EU law.

The conclusion drawn was that it is necessary to amend the key laws of Ukraine, as well as to carry out institutional reform, improve staffing in public procurement, and make other changes and additions to the existing regulations of Ukraine in order to bring the current legislation of Ukraine in line with the EU law in the field of public procurement. Necessary changes in the regulatory legal acts of Ukraine should provide for: new approaches to appealing against procurement procedures; changes in approaches to the organization of procurement; new tools in the electronic procurement system; introduction of simplified procurement; expansion of the list of competitive procurement procedures; changes in the approach to determining the criteria for evaluation of bids; detailed regulation of the use of technical specifications for the subject of procurement, which define the characteristics of goods (services, works) on the basis of the totality of all their technical specifications; expansion of the list of qualification criteria required by the customer from the participant of the order placement, etc.

Keywords: procurement, public procurement, tender, order, legal support, legislation.

\section{REFERENCES}

1. Pochynok K.B. (2013) Pravove rehuliuvannia rozvytku derzhavnykh zakupivel v Ukraini. "Legal regulation of public procurement development in Ukraine”. Scientific Bulletin of Kherson State University. No. 6. T. 1. P. 72-75. [in Ukrainian].

2. Vodolaskova K.Yu. (2013) Administratyvno-pravove rehuliuvannia derzhavnykh zakupivel v Ukraini. "Administrative and Legal Regulation of Public Procurement in Ukraine: Dis. Ph. D. in Low. K. 238 p. [in Ukrainian].

3. Pidmohylnyi O.O. (2012) Istoryko-pravovyi henezys rehuliuvannia zakupivel za derzhavni koshty v Ukraini. "Historical and legal genesis of public procurement regulation in Ukraine". State and regions. No. 4 (40). P. 61-65. [in Ukrainian]. 
4. Pro zatverdzhennia Stratehii rozvytku systemy derzhavnykh zakupivel na 2005-2010 roky. "On Approval of the Strategy of Development of the Public Procurement System for 2005-2010": Resolution of the Cabinet of Ministers of Ukraine of December 21, 1998, No. 1257. URL: https://zakon.rada.gov.ua/laws/main/1257-2005-\%D0\%BF (date of application: 15.10.2019) [in Ukrainian].

5. Orhanizatsiia publichnykh zakupivel: navch. posibnyk / A.M. Brovdii. "Public Procurement Organization": Educ. tool. Kharkiv. nat. un-t. O.M. Becketova. Kharkiv: KhNUMH O.M. Beketova, 2018. 183 p. [in Ukrainian].

6. Pro publichni zakupivli. "On Public Procurement": Law of Ukraine of December 25, 2015, No. 922-VIII.URL: https://zakon.rada.gov.ua/laws/show/92219\#n608 (date of application: 15.10.2019) [in Ukrainian].

7. Pro vnesennia zmin do Zakonu Ukrainy "Pro publichni zakupivli" ta deiakykh inshykh zakonodavchykh aktiv Ukrainy shchodo vdoskonalennia publichnykh zakupivel. "On Amendments to the Law of Ukraine "On Public Procurements" and some other legislative acts of Ukraine on the improvement of public procurement": Law of Ukraine of September 19, 2019, No. 114-IX. URL: https://zakon.rada.gov.ua/laws/show/114-20 (date of application: 15.10.2019) [in Ukrainian]. 